\title{
Metode Probing-Prompting dalam Meningkatkan Kemampuan Melengkapi Puisi bagi Siswa Sekolah Dasar
}

\author{
Reza Syehma Bahtiar \\ Universitas Wijaya Kusuma Surabaya \\ E-mail: syehma@gmail.com
}

\begin{abstract}
Abstrak
Sesuai dengan standar isi Kurikulum 2013 siswa diharapkan dapat melengkapi puisi berdasarkan gambar. Namun, pada kenyataannya dalam menemukan ide yang sesuai dengan gambar yang dilihatnya untuk dituangkan ke dalam bentuk puisi siswa mengalami kesulitan. Sehingga selama ini saat pembelajaran menulis puisi siswa masih mengalami kesulitan yaitu dalam berimajinasi sehingga sulit dalam menemukan katakata yang tepat untuk disusun menjadi sebuah puisi. Penelitian ini bertujuan untuk mengetahui peningkatan kemampuan melengkapi puisi melalui penggunaan metode probing prompting dalam pembelajaran. Jenis penelitian yang digunakan adalah deskriptif kualitatif. Penelitian deskriptif kualitatif merupakan penelitian yang bertujuan untuk menjelaskan atau mendeskripsikan suatu keadaan, peristiwa, objek yang bisa dijelaskan dengan kata-kata. Metode penelitian kualitatif digunakan untuk mendapatkan data yang mendalam. Penelitian ini dilaksanakan di SDN Jajartunggal III Surabaya yang dilaksakan pada tahun ajaran 2019/2020 pada semester ganjil. Subjek dalam penelitian ini adalah siswa kelas I Sekolah dasar dengan jumlah siswa 31 siswa yang terdiri dari 14 siswa perempuan dan 17 siswa laki-laki. Instrumen yang digunakan dalam penelitian ini menggunakan tes hasil belajar, observasi, dan wawancara. Untuk menjawab pertanyaan penelitian, maka data yang diperoleh dianalisis menggunakan analisis deskriptif. Data yang diperoleh meliputi ketuntasan belajar siswa, aktifitas siswa dalam pembelajaran, dan keefektifan dalam penggunaan metode pembelajaran probing-prompting. Berdasarkan hasil analisa data menunjukkan bahwa hasil belajar siswa mencapai ketuntasan klasikal sebesar 83,87\% (ketuntasan terpenuhi), hasil observasi aktivitas siswa dalam pembelajaran sebesar $90 \%$ (kategori aktif terpenuhi), dan hasil wawancara guru leluasa dalam mengajar (kategori positif terpenuhi). Berdasarkan hasil tersebut, maka metode probing-prompting mampu meningkatkan kemampuan melengkapi puisi siswa sekolah dasar.
\end{abstract}

Kata Kunci: metode probing-prompting, puisi, sekolah dasar

\author{
Probing-Prompting Method in Improving Students' Ability \\ to Complete Elementary Students' Poetry
}

\begin{abstract}
By the 2013 Curriculum content standards, students are expected to complete poetry based on images. However, in reality in finding ideas that are by the picture he saw to be poured into poetry, students had difficulty. So far, while learning to write poetry, students still experience difficulties in imagining, making it difficult to find the right words to compile a poem. This study aims to determine the increase in the ability to
\end{abstract}


complete poetry through the use of the probing prompting method in learning. The type of research used is descriptive qualitative. Qualitative descriptive research is research that aims to explain or describe a situation, event, the object that can be explained in words. Qualitative research methods are used to obtain in-depth data. This research was conducted at Jajartunggal III Surabaya Elementary School which was conducted in the 2019/2020 school year in the odd semester. The subjects in this study were grade 1 students of elementary schools with 31 students consisting of 14 female students and 17 male students. The instrument used in this study used tests of learning outcomes, observation, and interviews. To answer the research questions, the data obtained were analyzed using descriptive analysis. The data obtained include completeness of student learning, student activities in learning, and effectiveness in the use of probingprompting learning methods. Based on the results of data analysis shows that student learning outcomes achieve classical completeness of $83.87 \%$ (completeness fulfilled), observations of student activity activities in learning by $90 \%$ (active categories are met), and the results of teacher interviews are free in teaching (positive categories are met). Based on these results, the probing-prompting method can improve the ability to complete the poetry of elementary school students.

Keywords: probing-prompting method, poetry, elementary school

\section{PENDAHULUAN}

Bahasa merupakan alat komunikasi. Melalui bahasa manusia dapat saling berkomunikasi, saling berbagi pengalaman, saling belajar dari yang lain, dan saling meningkatkan kemampuan intelektual. Bahasa merupakan syarat mutlak bagi anak untuk aktif belajar. Untuk mengetahui dan memahami apa yang dipelajari, seorang siswa terutama harus mengerti bahasa yang digunakan, sehingga dengan mengerti bahasa yang digunakan dalam buku-buku, maka memudahkan baginya untuk aktif belajar. Mata Pelajaran Bahasa dan Sastra Indonesia adalah program untuk mengembangkan pengetahuan, keterampilan berbahasa, dan sikap positif terhadap bahasa Indonesia. Selain itu, pembelajaran bahasa Indonesia juga diarahkan untuk meningkatkan kemampuan siswa dalam berkomunikasi dengan bahasa Indonesia baik secara lisan maupun tertulis, meningkatkan kemampuan berpikir dan bernalar, serta kemampuan memperluas wawasan.

Pembelajaran bahasa Indonesia mencakup aspek mendengarkan (menyimak), berbicara, membaca, dan menulis. Keempat aspek tersebut harus dilaksanakan secara terpadu dan mendapat porsi yang seimbang.Menulis sebagaimana berbicara, merupakan keterampilan produktif dan ekspresif Pembelajaran bahasa Indonesia mencakup komponen berbahasa dan kemampuan bersastra. Kemampuan berbahasa memiliki 4 (empat) komponen, yaitu keterampilan menyimak (listening skill), keterampilan membaca (reading skill), keterampilan berbicara (speaking skill), dan keterampilan menulis (writing skill). Untuk menumbuhkan semangat peserta didik dalam bersastra dengan baik, pendidik dapat memberikan rangsangan (apersepsi) yang menarik sehingga dapat memotivasi peserta didik untuk menggali dan mengembangkan kemampuan dirinya dalam mengasah keterampilan bersastra. 
Dalam kehidupan sehari-hari menulis mempunyai fungsi utama yaitu sebagai alat komunikasi tidak langsung, oleh karena itu dalam menulis yang paling penting adalah dapat menyampaikan pesan kepada pembaca sehingga pembaca memahami maksud yang dituangkan dalam tulisan. Kemampuan menulis merupakan salah satu kemampuan dasar yang sangat diperlukan baik di sekolah maupun dalam kehidupan sehari-hari. Di sekolah diperlukan dalam kegiatan mencatat, menyalin, dan menyusun/membuat karya tulis pada semua mata pelajaran mulai di tingkat pendidikan dasar sampai dengan pendidikan tinggi, sedangkan dalam kegiatan sehari-hari kemampuan menulis diperlukan dalam kegiatan tulis menulis (berbahasa tulis) pada semua bidang kehidupan, misalnya digunakan dalam transaksi jual beli (menulis nota belanja), membuat surat, atau yang lainnya. Kegiatan menulis dapat bermanfaat bagi seseorang untuk mengungkapkan gagasan agar dibaca dan dipahami oleh pembaca. Dengan menulis, seseorang mampu mengungkapkan gagasan secara sistematis, jelas, logis, serta mampu berkomunikasi sesuai dengan konteks (Oktaria et al., 2017). Keterampilan menulis sebagai sarana mengekspresikan ide gagasan dalam bentuk tulisan. Isi tulisan yang dibuat siswa tentu sangat beragam sesuai dengan isi materi yang dipelajarinya (Susilo \& Ramdiati, 2019). Selanjutnya (Meilasari et al., 2018) menambahkan Keterampilan menulis merupakan salah satu keterampilan berbahasa yang cukup sulit. Keterampilan menulis perlu dikembangkan dalam dunia pendidikan untuk melatih siswa berpikir kritis dalam menanggapi sesuatu, karena itu untuk dapat menguasai keterampilan menulis maka harus terus berlatih dan berlatih. Sehingga keterampilan menulis diajarkan dengan tujuan agar siswa mempunyai kemampuan dalam menuangkan ide, gagasan, pikiran, pengalaman, dan pendapatnya dengan benar. Begitu juga dalam keterampilan siswa menulis puisi ataupun melengkapi puisi, siswa dituntut untuk dapat menuangkan ide, gagasan, pikiran, pengalaman, atau pendapatnya kedalam bentuk puisi.

Dalam pembelajaran Bahasa Indonesia kelas I sesuai dengan standar isi Kurikulum 2013 siswa diharapkan dapat melengkapi puisi berdasarkan gambar. Namun, pada kenyataannya dalam menemukan ide yang sesuai dengan gambar yang dilihatnya untuk dituangkan ke dalam bentuk puisi siswa mengalami kesulitan. Berdasarkan wawancara yang penulis lakukan bersama guru kelas I SDN Jajartunggal III Surabaya, diperoleh hasil bahwa selama ini disaat pembelajaran menulis puisi siswa masih mengalami kesulitan yaitu dalam berimajinasi sehingga sulit dalam menemukan kata-kata yang tepat untuk disusun menjadi sebuah puisi. Pembelajaran melengkapi puisi di Sekolah Dasar merupakan pembelajaran yang berkenaan dengan menulis puisi yaitu dengan cara melengkapi baris puisi dengan kata-katanya sendiri sehingga menjadi bait puisi, selain itu siswa juga harus bisa mempresentasikannya, dua hal yang tidak terpisahkan karena orientasi dari pembelajaran adalah kompetensi berpuisi. Dengan kata lain pembelajaran melengkapi puisi adalah pembelajaran yang penekanannya yaitu pada aspek kinerja atau praktik langsung membuat puisi. Dalam pembelajaran ini, siswa kelas III Sekolah Dasar tidak perlu penekanan secara teori tentang istilahistilah dalam berpuisi akan tetapi yang lebih penting adalah bagaimana praktek membuat dan mempresentasikan puisi, yang materinya sesuai dengan 
kehidupan siswa sehari-hari, dengan menggunakan pembendaharaan kata yang luas, susunan kata-kalimat yang logis, gaya bahasa yang tepat, dan memuat unsur esensial puisi yaitu rima, ritme, diksi, larik, amanat, irama, dan tipografi. Puisi adalah ragam karya sastra yang menggunakan bahasa atau peristiwa kebahasaan sebagai mediumnya sebagai usaha untuk mengekspresikan kepribadian pengarang yang mungkin berisikan pesan atau gambaran suasana tertentu, baik fisk maupun batin (Citraningrum, 2016). Selanjutnya (Fadhillah, 2019) menambahkan bahwa keterampilan menulis bagi siswa merupakan keterampilan yang paling sulit. Mereka harus mampu menyusun kata-kata ke dalam sebuah puisi. Banyak siswa yang sangat kesulitan menulis sebuah puisi daripada menulis sebuah karangan. Keterampilan menulis puisi perlu ditanamkan kepada siswa sejak dini, sehingga mereka mempunyai kemampuan untuk mengapresiasikan puisi dengan baik. Mengapresiasikan sebuah puisi bukan hanya ditujukan untuk penghayatan dan pemahaman puisi, melainkan berpengaruh mempertajam terhadap kepekaan perasaan, penalaran, serta kepekaan anak terhadap masalah kemanusiaan (Rahmadani et al., 2015). Pada dasarnya menulis puisi merupakan suatu kegiatan yang mencerminkan keadaan masyarakat, artinya menulis puisi tidak bertolak dari kekosongan, tetapi selalu berangkat dari kenyataan. Kemampuan menulis puisi merupakan kemampuan mewujudkan gagasan yang dilakukan secara tertulis dengan bahasa yang padat dan ekspresif (Ika \& Riana, 2016). Berdasarkan kedua pendapat tersebut, penulis menyimpulkan bahwa menulis puisi merupakan kegiatan melukis atau mencerminkan suatu obyek yang nyata dalam bentuk teks yang didasari oleh pikiran dalam perasaan/jiwa penyair/penulis puisi sebagai suatu karya sastra, demikian juga dalam melengkapi puisi kegiatan yang dilakukan yaitu meneruskan atau melengkapi puisi yang sudah ada dengan ungkapan jiwa penulis berdasarkan ilustrasi yang ada.

Dengan adanya permasalahan tersebut, penulis berupaya untuk mengatasinya yaitu mengubah strategi pembelajaran yang biasanya dipakai, yaitu strategi pembelajaran langsung diubah menjadi strategi pembelajaran kontekstual dengan metode probingprompting. Metode pembelajaran Probing Prompting Learning (PPL) dapat meningkatkan tanggung jawab pada siswa tentang hal-hal yang dipelajari dengan cara yang menyenangkan (Dewi \& Kocimaheni, 2019). Probing prompting question adalah pertanyaan yang diajukan untuk mengarahkan siswa ke pemahaman konsep dan pertanyaan yang diajukan untuk pendalaman konsep dalam memecahkan suatu permasalahan (Firdaus, 2019). Sedangkan (Kariani et al., 2014) menambahkan menurut arti katanya, Probing adalah penyelidikan dan pemeriksaan sedangkan Prompting berarti mendorong atau menuntun. Pembelajaran dengan menggunakan metode Probing-Prompting berkaitan erat dengan pertanyaan. Seingga jika dikaitkan dengan pembelajaran melengkapi puisi tersebut, guru memberi pertanyaan-pertanyaan kepada siswa untuk memancing daya imajinasi siswa.

Metode probing promting erat kaitannya dengan keterampilan bertanya. Keterampilan bertanya harus dikuasai oleh guru sehingga saat kegiatan belajar mengajar di kelas, pertanyaan diberikan kepada siswa memiliki makna yang mudah dipahami oleh siswa. Keterampilan bertanya 
terdiri dari keterampilan bertanya dasar dan keterampilan bertanya lanjut. Hal ini akan dijeliskan legih lanjut pada table dibawah ini.

\section{Tabel 1. Keterampilan bertanya dasar}

\begin{tabular}{|c|c|c|}
\hline No & $\begin{array}{c}\text { Keterampilan } \\
\text { Bertanya }\end{array}$ & Deskripsi \\
\hline 1 & $\begin{array}{l}\text { Pengungkapan } \\
\text { Pertanyaan } \\
\text { Secara Jelas } \\
\text { dan Singkat }\end{array}$ & $\begin{array}{lr}\text { Pertanyaan guru harus } \\
\text { diungkapkan } & \text { secara } \\
\text { jelas dan } & \text { singkat, } \\
\text { sehingga } & \text { dapat } \\
\text { dipahami siswa. Selain } \\
\text { itu susunan kata-kata } \\
\text { dalam pertanyaan perlu } \\
\text { disesuaikan dengan } \\
\text { usia dan tingkat } \\
\text { perkembangan siswa. }\end{array}$ \\
\hline 2 & $\begin{array}{l}\text { Pemberian } \\
\text { Acuan }\end{array}$ & 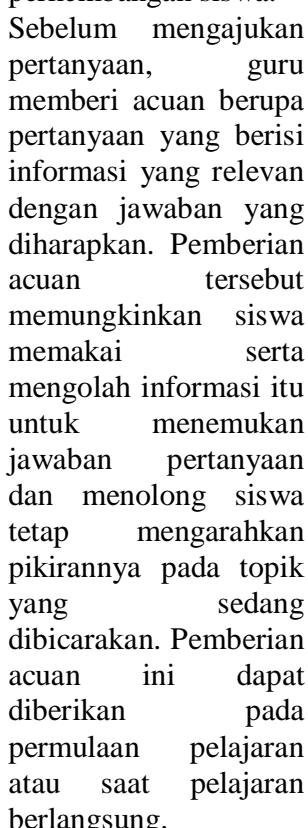 \\
\hline 3 & Pemusatan & $\begin{array}{lr}\text { Dalam } & \text { memberi } \\
\text { pertanyaan, } & \text { pertama- } \\
\text { tama } & \text { gunakan } \\
\text { pertanyaan } & \text { yang } \\
\text { berfokus } & \text { luas } \\
\text { kemudian } & \text { diikuti } \\
\text { pertanyaan yang lebih } \\
\text { khusus, yang berfokus } \\
\text { sempit. }\end{array}$ \\
\hline 4 & $\begin{array}{l}\text { Pemindahan } \\
\text { Giliran }\end{array}$ & $\begin{array}{l}\text { Ajukan pertanyaan } \\
\text { kepada seluruh siswa } \\
\text { dalam kelas kemudian } \\
\text { pilih beberapa siswa } \\
\text { untuk menjawab } \\
\text { dengan menyebutkan } \\
\text { nama mereka secara } \\
\text { bergilir. }\end{array}$ \\
\hline 5 & Penyebaran & $\begin{array}{l}\text { Pengajuan pertanyaan } \\
\text { dilakukan secara acak } \\
\text { dan merata kepada } \\
\text { siswa dimaksudkan }\end{array}$ \\
\hline
\end{tabular}

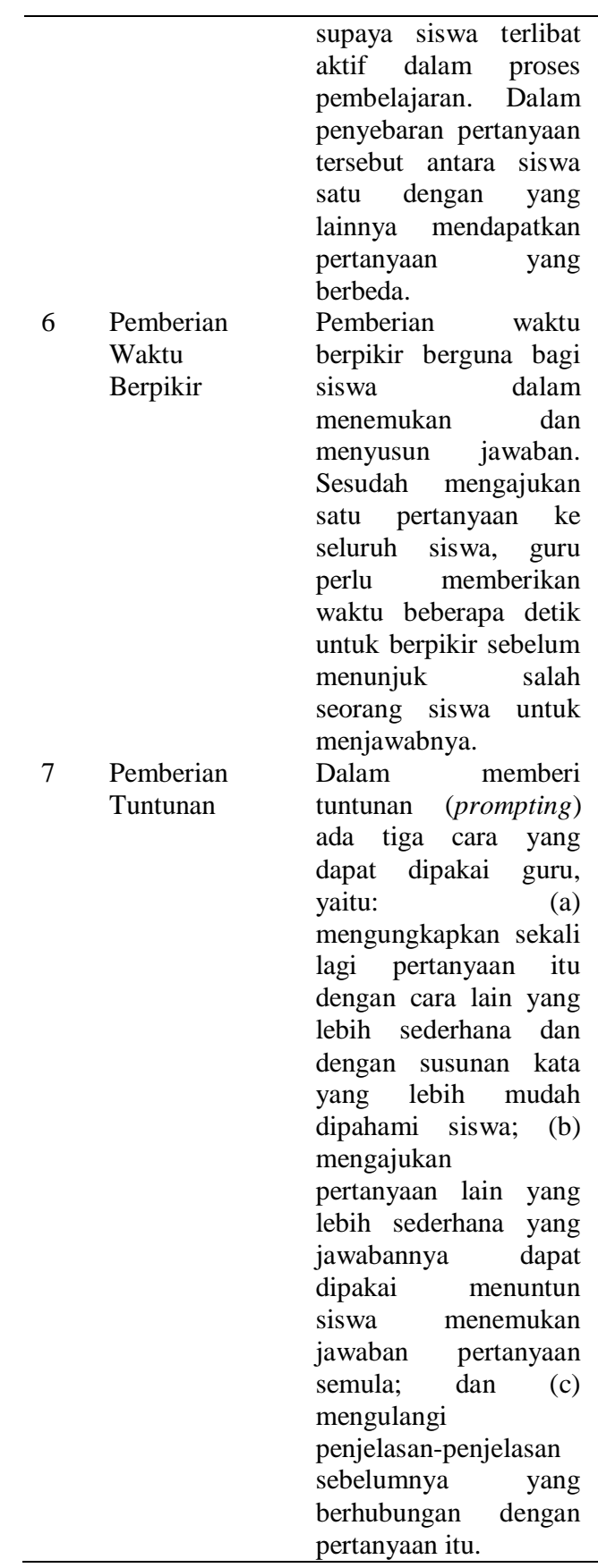

Tabel 2. keterampilan bertanya lanjut

\begin{tabular}{|c|c|c|}
\hline No & $\begin{array}{c}\text { Keterampilan } \\
\text { Bertanya }\end{array}$ & Deskripsi \\
\hline 1 & $\begin{array}{l}\text { Pengubahan } \\
\text { Tuntutan } \\
\text { Tingkat } \\
\text { Kognitif dalam } \\
\text { Menjawab } \\
\text { Pertanyaan }\end{array}$ & $\begin{array}{l}\text { Pertanyaan- } \\
\text { pertanyaan disusun } \\
\text { dengan } \\
\text { memperhatikan } \\
\text { taksonomi Bloom } \\
\text { yang terdiri dari } \\
\text { ingatan, pemahaman, } \\
\text { penerapan, analisis, } \\
\text { sintesa, dan evaluasi. }\end{array}$ \\
\hline 2 & $\begin{array}{l}\text { Pengaturan } \\
\text { Urutan } \\
\text { Pertanyaan }\end{array}$ & $\begin{array}{l}\text { Pertanyaan yang } \\
\text { diajukan kepada siswa } \\
\text { untuk }\end{array}$ \\
\hline
\end{tabular}




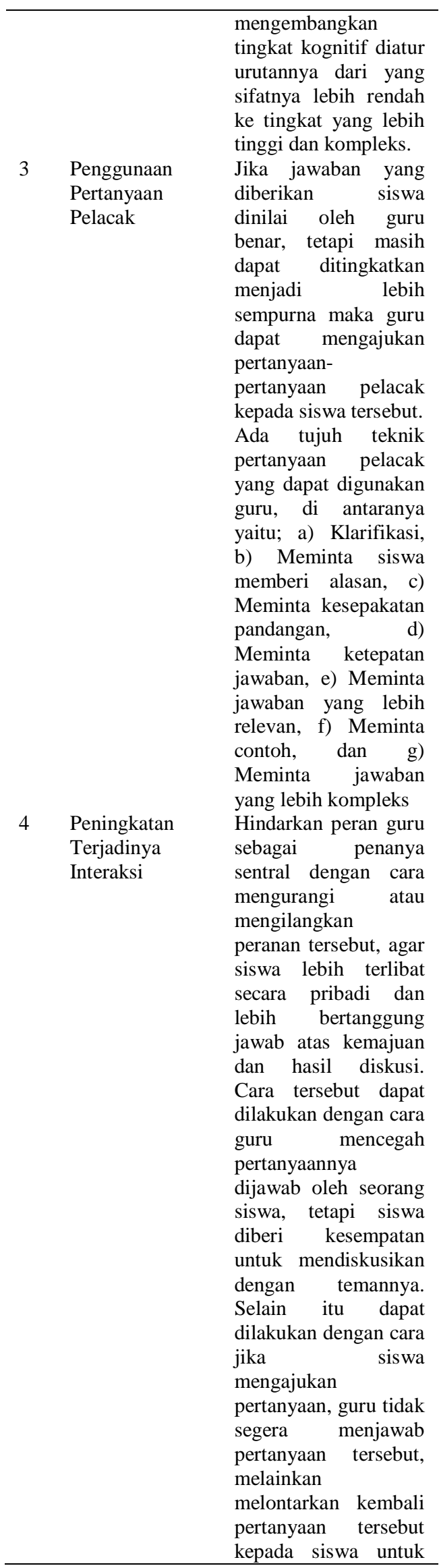

\begin{tabular}{llr}
\hline didiskusikan agar & dapat \\
siswa & \\
mempelajari & \\
& bagaimana cara \\
& memberi komentar \\
& yang wajar terhadap \\
pertanyaan temannya.
\end{tabular}

Pada penelitian ini juga mengacu pada penelitian-penelitian sebelumnya. Penelitian-penelitian tersebut antara lain (1) pada tahun 2016 penelitian Taufik Nur Rahmadi dengan judul Pengaruh Penerapan Metode Probing-Prompting pada Pembelajaran IPA SMP Kelas VII Terhadap Kemampuan Berpikir Kritis Siswa dengan hasil terdapat perbedaan kemampuan berpikir kritis antara kelas VII yang menggunakan metode probing-promptingvdan kelas VII yang menggunakan metode direct instruction pada pembelajaran IPA di SMP $\mathrm{N} 4$ Wonosari semester genap tahun pelajaran 2015/2016 dengan nilai (thitung $=3,018>$ ttabel $=2,007$ ) pada taraf signifikansi 5\%; dan 2) besarnya pengaruh dari penerapan metode pembelajaran probing prompting terhadap kemampuan berpikir kritis siswa kelas VII SMP Negeri 4 Wonosari semester genap tahun pelajaran 2015/2016 adalah $62,61 \%$ dari pengambilan data menggunakan instrumen tes dan 69,72\% menggunakan instrument nontes; (2) pada tahun 2015 penelitian Ani Royani dengan judul Penerapan Metode Probing Prompting nntuk Meningkatkan Motivasi Belajar Siswa Bidang Studi IPS Kelas VII SMP Negeri 3 Palimanan Cirebon dengan hasil Penggunaan metode pembelajaran Probing Prompting dalam pembelajaran IPS (Ekonomi) dapat diterapkan dengan baik pada siswa kelas VII E SMP Negeri 3 Palimanan Cirebon. Hal ini dapat dilihat dari hasil observasi guru dan aktivitas siswa. Pada siklus I hasil observasi aktivitas siswa sebesar $57.5 \%$ 
sedangkan kinerja guru sebesar $65 \%$ dan ketuntasan belajar klasikal sebesar $27.77 \%$. Pada siklus II observasi aktivitas siswa sebesar $80 \%$ sedangkan kinerja gurunya sebesar $82.5 \%$ dan ketuntasan belajar klasikal sebesar $52.77 \%$. Adapun pada siklus III observasi aktivitas siswa sebesar $92.5 \%$ sedangkan kinerja gurunya sebesar 97.5 $\%$ dan ketuntasan belajar klasikalnya sebesar $100 \%$, dari hasil pengamatan peningkatan motivasi belajar siswa dapat di simpulkan sebagai berikut. Pada siklus I siswa yang termotivasi dalam belajar pada pokok bahasan kegiatan pokok ekonomi sebanyak 10 siswa dengan nilai ketuntasan belajarnya sebesar $27.77 \%$. Pada siklus II siswa yang termotivasi dalam belajar dalam pokok bahasan kegiatan pokok ekonomi sebanyak 19 siswa dengan nilai ketuntasan belajarnya sebesar $52.77 \%$. Kemudian pada siklus III siswa yang termotivasi dalam belajar dalam pokok bahasan kegiatan pokok ekonomi sebanyak 36 siswa dengan nilai ketuntasan belajarnya sebesar $100 \%$ tuntas. Sesuai dengan KKM yaitu 75 . Semua siswa sudah mencapai KKM maka oleh karena itu $100 \%$ ini termasuk kategori sangat baik, peningkatan hasil belajar siswa pada materi kegiatan pokok ekonomi setelah menggunakan metode Probing Prompting sebagai berikut. Pada siklus I hasil belajar siswa pada setiap akhir siklus nilai rata-rata siswa sebesar 67.22 kemudian pada siklus II hasil belajar dengan nilai ratarata siswa sebesar 73.33 dan pada siklus III hasil belajar siswa nilai rataratanya sebesar 83.75 dengan kategori sangat baik sebab berada pada rentang 81\%-100. Hal ini menunjukan bahwa dalam masingmasing siklus ini terlihat adanya suatu peningkatan karena sudah mencapai KKM; (3) penelitian Fajar Gumelar pada tahun 2016 dengan judul Efektivitas Metode Probing Prompting
Learning dalam Pembelajaran Menulis Argumentasi dengan hasil kemampuan menulis argumentasi kelas eksperimen sebelum mengikuti pembelajaran menggunakan metode probing prompting learning berada dalam kategori kurang. Hal ini terbukti dari rata - rata nilai pretest menulis argumentasi kelas eksperimen adalah 65,65. Kemampuan menulis argumentasi kelas eksperimen setelah mengikuti pembelajaran menggunakan metode probing prompting learning berada dalam kategori yang lebih baik. Hal ini terbukti dari rata - rata nilai postes menulis argumentasi kelas eksperimen adalah 76,4. Perubahan nilai rata - rata tersebut menjadi bukti adanya pengaruh metode pembelajaran probing prompting learning terhadap kemampuan siswa dalam menulis argumentasi. Rata - rata kemampuan menulis argumentasi kelas kontrol sebelum mendapatkan perlakukan pembelajaran oleh guru yang lain adalah 66,06. Sedangkan sesudah mendapatkan perlakuaan pembelajaran yang dilakukan guru Bahasa Indonesia yang lain dengan tidak menggunakan metode pembelajaran probing prompting learning adalah 72,9. Terdapat perbedaan yang signifikan antara kemampuan menulis argumentasi peserta didik di kelas eksperimen yangmendapatkan perlakuan pembelajaran dengan menggunakan metode probing prompting learning dengan kemampuan menulis argumentasi peserta didik kelas kontrol yang mendapatkan perlakukan pembelajaran dengan metode pembelajaran yang lain. Berdasarkan perhitungan uji $\mathrm{t}$, diperoleh thitung sebesar 2,59 sedangkan ttabel $(\alpha 0,05)$ diperoleh sebesar 2,03. Maka dapat kita ketahui ttabel < thitung > ttabel yaitu $2,03<2,59>2,03$ sehingga $\mathrm{H} 1$ diterima. Oleh karena itu dapat 
disimpulkan $\mathrm{H} 1$ diterima sedangkan $\mathrm{H} 0$ ditolak, artinya terdapat perbedaan yang signifikan antara kemampuan menulis argumentasi peserta didik kelas eksperimen dengan peserta didik kelas kontrol. Hal tersebut menandakan bahwa penggunaan metode probing prompting learning pada pembelajaran menulis argumentasi lebih dapat meningkatkan kemampuan menulis argumentasi peserta didik dibanding dengan metode pembelajaran yang telah digunakan guru bahasa Indonesia yang lain saat pembelajaran argumentasi; (4) penelitian Kariani dkk pada tahun 2014 dengan judul Model Problem Based Learning Menggunakan Metode Probing - Prompting Berpengaruh Terhadap Hasil Belajar IPA Siswa dengan hasil analisis uji hipotesis menggunakan uji $\mathrm{t}$ diperoleh thitung > ttabel pada taraf signifikansi 5\% $(\alpha$ $=0,05)$ dengan $\mathrm{dk}=78$ yaitu thitung $=$ $4,83>$ ttabel $=2,00$. Selain itu, berdasarkan hasil penelitian serta analisis yang telah dilakukan menunjukkan pula bahwa ratarata nilai pada kelompok eksperimen lebih besar dibandingkan dengan rata-rata nilai pada kelompok kontrol yaitu $=80,34>$ $=71,17$. Hal ini menunjukkan bahwa hipotesis alternative (Ha) diterima yang berarti terdapat perbedaan yang signifikan hasil belajar IPA antara siswa yang dibelajarkan melalui penerapan model Problem Based Learning menggunakan metode Probing Prompting dengan yang dibelajarkan melalui pembelajaran konvensional pada siswa kelas V SD Negeri 21 Pemecutan Tahun Ajaran 2013/2014. Berdasarkan perbedaan nilai rata-rata kedua kelompok dan hasil uji hipotesis, maka dapat disimpulkan bahwa penerapan model Problem Based Learning menggunakan metode Probing-Prompting berpengaruh terhadap hasil belajar IPA siswa kelas V
SD Negeri 21 Pemecutan Denpasar Utara Tahun Ajaran 2013/2014.

\section{METODE}

Jenis penelitian yang digunakan adalah deskriptif kualitatif. Penelitian deskriptif kualitatif merupakan penelitian yang bertujuan untuk menjelaskan atau mendeskripsikan suatu keadaan, peristiwa, objek yang bisa dijelaskan dengan kata-kata. Metode penelitian kualitatif digunakan untuk mendapatkan data yang mendalam, suatu data yang mengandung makna. Makna adalah data yang sebenarnya, data yang pasti yang merupakan suatu nilai di balik data yang tampak.

Penelitian ini dilaksanakan di SDN Jajartunggal III Surabaya yang dilaksakan pada tahun ajaran 2019/2020 pada semester ganjil. Subjek dalam penelitian ini adalah siswa kelas I Sekolah dasar dengan jumlah siswa 31 siswa yang terdiri dari 14 siswa perempuan dan 17 siswa laki-laki.

Instrumen yang digunakan dalam penelitian ini menggunakan tes hasil belajar, observasi, dan wawancara. Lembar tes hsil belajar digunakan untuk mengetahui ketuntasan belajar siswa, lemba observasi digunakan untuk mengetahui aktifitas siswa, dan instrument wawancara digunakan untuk mengetahui efektifitas metode probing promting yang dilakukan dalam pembelajaran

Untuk menjawab pertanyaan penelitian, maka data yang diperoleh dianalisis menggunakan analisis deskriptif. Data yang diperoleh meliputi ketuntasan belajar siswa, aktifitas siswa dalam pembelajaran, dan keefektifan dalam penggunaan metode pembelajaran probing-prompting. Data-data tersebut dijabarkan dalam uraian berikut ini: (1) Analisis data hasil belajar siswa dilihat dari ketuntasan hasil belajar siswa 
selama mengikuti pembelajaran menulis puisi yaitu pada nilai akhir dalam tes individu. Siswa akan dinyatakan lulus apabila siswa mendapatkan nilai lebih dari atau sama dengan 75 dari nilai standart sempurna yaitu 100, dan suatu kelas dinyatakan tuntas dalam belajar apabila terdapat lebih dari atau sama dengan $75 \%$ siswa mencapai ketuntasan; (2) untuk menganalisis data hasil pengamatan aktivitas siswa dalam setiap aspek selama proses pembelajaran digunakan rumus presentase $(\%)=\mathrm{f} / \mathrm{N} \mathrm{x}$ $100 \%$, adapun rumus untuk menghitung presentase rata-rata adalah $\mathrm{NR}=$ $\left(\sum \mathrm{X}\right) /\left(\sum \mathrm{N}\right) ; \quad$ (3) untuk mengetahui keefektifan dalam penggunaan metode pembelajaran probing-prompting maka digunakan bentuk wawancara secara langsung kepada guru.

\section{HASIL DAN PEMBAHASAN}

Berikut ini akan dibahas tentang data hasil belajar siswa dalam pembelajaran materi melengkapi puisi. Data tersebut disajikan dalam Tabel 3.

Tabel 3. Data Hasil Belajar Siswa dalam Pembelajaran Sekolah dasar

\begin{tabular}{|c|c|c|c|}
\hline No & Inisial Nama Siswa & Nilai & Keterangan \\
\hline 1 & AM. & 80 & Tuntas \\
\hline 2 & $\mathrm{AD}$ & 80 & Tuntas \\
\hline 3 & $\mathrm{AN}$ & 70 & Tidak Tuntas \\
\hline 4 & AR & 50 & Tidak Tuntas \\
\hline 5 & ADR. & 100 & Tuntas \\
\hline 6 & APP. & 100 & Tuntas \\
\hline 7 & ASY & 80 & Tuntas \\
\hline 8 & AMP & 50 & Tidak Tuntas \\
\hline 9 & ADA & 70 & Tidak Tuntas \\
\hline 10 & AGA & 100 & Tuntas \\
\hline 11 & $\mathrm{ABJ}$ & 90 & Tuntas \\
\hline 12 & $\mathrm{CN}$ & 100 & Tuntas \\
\hline 13 & DF & 80 & Tuntas \\
\hline 14 & FMP & 90 & Tuntas \\
\hline 15 & FAV & 70 & Tidak Tuntas \\
\hline 16 & IRP & 90 & Tuntas \\
\hline 17 & KQ & 90 & Tuntas \\
\hline 18 & MA & 90 & Tuntas \\
\hline 19 & MAM & 80 & Tuntas \\
\hline 20 & $\mathrm{MBF}$ & 80 & Tuntas \\
\hline 21 & MAR & 90 & Tuntas \\
\hline 22 & MOT & 80 & Tuntas \\
\hline 23 & NNI & 100 & Tuntas \\
\hline 24 & $\mathrm{NF}$ & 100 & Tuntas \\
\hline 25 & ODF & 100 & Tuntas \\
\hline
\end{tabular}

\begin{tabular}{llll}
26 & PAS & 100 & Tuntas \\
27 & RW & 100 & Tuntas \\
28 & RD & 80 & Tuntas \\
29 & SZM. & 100 & Tuntas \\
30 & VBP & 100 & Tuntas \\
31 & ZA & 100 & Tuntas \\
\hline
\end{tabular}

Dari data di atas maka perhitungan untuk mengetahui siswa yang tuntas secara klasikal pada pembelajaran materi melengkapi puisi sebagai berikut:

Ketuntasan Klasikal $=$ Banyaknya siswa yang tuntas $x 100 \%$ Jumlah Siswa

Ketuntasan Klasikal $=$ $\frac{26}{31} \times 100=83,87 \%$

Sedangkan siswa yang tidak tuntas secara klasikal dapat dihitung menggunakan cara sebagai berikut: $100 \%-83,87 \%=16,13 \%$

Sehingga dapat digambarkan dengan diagram 1

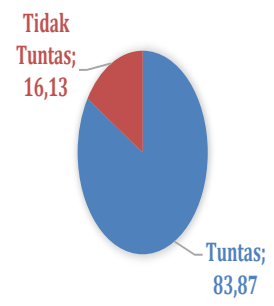

\section{Diagram 1. Data Hasil Belajar Siswa dalam Pembelajaran Sekolah dasar}

Berdasarkan penelitian yang dilakukan di kelas I SDN Jajartunggal III Surabaya dengan menggunakan kurikulum 2013, siswa dikatakan tuntas belajar secara individu apabila skor yang diperoleh minimal atau $\geq 75$ sedangkan siswa dianggap tuntas belajar secara klasikal apabila skor yang diperoleh $70 \%$ dari jumlah siswa. Dari data yang disajikan pada tabel 1 dan diagram 1 terdapat 26 siswa yang tuntas belajar dengan presentase secara klasikal 83,87 $\%$ sedangkan siswa yang tidak tuntas belajar sebanyak 5 siswa dengan presentase secara klasikal 16,13\%. 
Dengan demikian penelitian dikatakan berhasil apabila mencapai ketuntasan belajar $\geq 75$ sehingga dapat dikatakan bahwa metode probing-prompting mampu meningkatkan kemampuan melengkapi puisi dengan memeroleh presentase tinggi.

Berikut ini akan dibahas tentang data aktivitas siswa dalam pembelajaran materi melengkapi puisi. Data tersebut disajikan dalam tabel berikut:

\begin{tabular}{cccc}
\multicolumn{5}{c}{ Tabel 3. Data Aktivitas Siswa dalam } \\
Pembelajaran Sekolah dasar \\
\hline No & $\begin{array}{c}\text { Aspek Belajar Siswa (Aspek } \\
\text { Perhatian) }\end{array}$ & $\begin{array}{c}\text { Jumlah } \\
\text { Siswa }\end{array}$ & $(\%)$ \\
\hline 1. & $\begin{array}{l}\text { Memperhatikan penjelasan / } \\
\text { mendengarkan guru }\end{array}$ & 30 & 96,7 \\
2. & $\begin{array}{l}\text { Tidak mengganggu teman / } \\
\text { Tidak berbicara ketika guru } \\
\text { menjelaskan }\end{array}$ & 29 & 93,5 \\
3. Fokus pada diskusi kelompok & 25 & 80,6 \\
Presentase Nilai Rata-Rata & 90.3 \\
\hline
\end{tabular}

\begin{tabular}{|c|c|c|c|c|c|}
\hline No & $\begin{array}{r}\text { Aspek Belaj } \\
\text { Pem }\end{array}$ & $\begin{array}{l}\text { r Siswa (A } \\
\text { haman) }\end{array}$ & spek & $\begin{array}{c}\text { Jumlah } \\
\text { Siswa }\end{array}$ & $(\%)$ \\
\hline 1. & $\begin{array}{l}\text { Mengomentari } \\
\text { menyimpulkan } \\
\text { pembelajaran }\end{array}$ & & $\begin{array}{r}\text { dan } \\
\text { proses }\end{array}$ & 28 & $90,3 \%$ \\
\hline 2. & $\begin{array}{l}\text { Memperbaiki } \\
\text { kekurangan } \\
\text { pembelajaran }\end{array}$ & $\begin{array}{l}\text { kesalahan } \\
\text { dalam }\end{array}$ & $\begin{array}{r}\text { atau } \\
\text { proses }\end{array}$ & 29 & $93,5 \%$ \\
\hline 3. & $\begin{array}{l}\text { Menyimpulkan } \\
\text { pembelajaran } \\
\text { katanya sendiri }\end{array}$ & dengan & $\begin{array}{l}\text { materi } \\
\text { kata- }\end{array}$ & 25 & $80,6 \%$ \\
\hline \multicolumn{5}{|c|}{ Presentase Nilai Rata-Rata } & $88.1 \%$ \\
\hline \multicolumn{5}{|c|}{ Total Rata-Rata 4 Aspek Belajar Siswa } & $90 \%$ \\
\hline
\end{tabular}

\section{Dalam pengamatan aktivitas} siswa dalam pembelajaran, peneliti membawa absensi dan pedoman pengamatan. Peneliti akan mengamati aktivitas sesuai dengan pedoman pengamatan dengan mencatat jumlah siswa yang disesuaikan dengan setiap aktivitas yang terdapat pada pedoman pengamatan. Terdapat empat aspek belajar siswa dan di setiap aspek tersebut terbagi menjadi beberapa aktivitas siswa. Keempat aspek belajar siswa tersebut adalah:

Pada aspek perhatian presentase nilai rata-rata yang diperoleh adalah 90,3 $\%$. Dengan rincian aktivitas belajar yang

\begin{tabular}{|c|c|c|c|}
\hline No & $\begin{array}{c}\text { Aspek Belajar Siswa (Aspek } \\
\text { Keaktifan) }\end{array}$ & $\begin{array}{l}\text { Jumlah } \\
\text { Siswa }\end{array}$ & $(\%)$ \\
\hline 1. & $\begin{array}{l}\text { Melakukan pengamatan atau } \\
\text { melengkapi teks puisi } \\
\text { dengan baik }\end{array}$ & 31 & $100 \%$ \\
\hline 2. & $\begin{array}{l}\text { Membaca dengan aktif (misal } \\
\text { dengan pensil/bulpoin di } \\
\text { tangan untuk menggaris } \\
\text { bawahi atau membuat catatan } \\
\text { kecil atau tanda-tanda tertentu } \\
\text { pada buku) }\end{array}$ & 29 & $93,5 \%$ \\
\hline 3. & $\begin{array}{l}\text { Mendengarkan dengan aktif } \\
\text { (menunjukkan respon, misal } \\
\text { tersenyum atau tertawa saat } \\
\text { mendengar hal-hal lucu yang } \\
\text { disampaikan, terkagum-kagum } \\
\text { bila mendengar sesuatu yang } \\
\text { menakjubkan, dsb) }\end{array}$ & 28 & $90,3 \%$ \\
\hline \multicolumn{2}{|c|}{ Presentase Nilai Rata-Rata } & & $94,6 \%$ \\
\hline No & $\begin{array}{c}\text { Aspek Belajar Siswa (Aspek } \\
\text { Partisipasi) } \\
\end{array}$ & $\begin{array}{l}\text { Jumlah } \\
\text { Siswa }\end{array}$ & $(\%)$ \\
\hline 1. & \begin{tabular}{ll}
\multicolumn{3}{c}{ Berlatih (misalnya mencobakan } \\
sendiri konsep-konsep misal \\
berlatih dengan soal-soal)
\end{tabular} & 28 & $90,3 \%$ \\
\hline 2. & $\begin{array}{l}\text { Mampu menjelaskan dan } \\
\text { mengemukakan pendapat }\end{array}$ & 26 & $83,9 \%$ \\
\hline 3. & Berdiskusi & 27 & $87,1 \%$ \\
\hline Presel & ase Nilai Rata-Rata & & $87,1 \%$ \\
\hline
\end{tabular}

pertama jumlah siswa yang memperhatikam penjelasan / mendengarkan guru adalah 30 siswa dari seluruh siswa kelas 1D dengan presentase sebesar 96,7 \%. Aktivitas belajar yang kedua jumlah siswa yang tidak mengganggu teman / tidak berbicara ketika guru menjelaskan adalah 29 siswa dari seluruh siswa kelas 1D dengan presentase sebesar 93,5\%. Aktivitas belajar yang ketiga jumlah siswa yang fokus pada diskusi kelompok adalah 25 siswa dari seluruh siswa kelas 1D dengan presentase sebesar 80,6\%.

Pada aspek keaktifan presentase nilai rata-rata yang diperoleh adalah 94,6 $\%$. Dengan rincian aktivitas belajar yang pertama jumlah siswa yang melakukan pengamatan atau melengkapi teks puisi dengan baik adalah 31 siswa dari seluruh siswa kelas 1D dengan presentase sebesar $100 \%$. Aktivitas belajar yang kedua jumlah siswa yang membaca dengan aktif adalah 29 siswa dari seluruh siswa kelas 1D dengan presentase sebesar 93,5 \%. Aktivitas belajar yang ketiga jumlah siswa yang 
mendengarkan dengan aktif adalah 28 siswa dari seluruh siswa kelas 1D dengan presentase sebesar 90,3\%.

Pada aspek partisipasi presentase nilai rata-rata yang diperoleh adalah 87,1 $\%$. Dengan rincian aktivitas belajar yang pertama jumlah siswa yang berlatih (misalnya mencobakan sendiri konsepkonsep misal berlatih dengan soal-soal) adalah 28 siswa dari seluruh siswa kelas 1D dengan presentase sebesar 90,3\%. Aktivitas belajar yang kedua jumlah siswa yang mampu menjelaskan dan mengemukakan pendapat adalah 26 siswa dari seluruh siswa kelas 1D dengan presentase sebesar 83,9 \%. Aktivitas belajar yang ketiga jumlah siswa yang berdiskusi adalah 27 siswa dari seluruh siswa kelas 1D dengan presentase sebesar $87,1 \%$.

Pada aspek partisipasi presentase nilai rata-rata yang diperoleh adalah 88,1 $\%$. Dengan rincian aktivitas belajar yang pertama jumlah siswa yang mengomentari dan menyimpulkan proses pembelajaran adalah 28 siswa dari seluruh siswa kelas 1D dengan presentase sebesar 90,3 \%. Aktivitas belajar yang kedua jumlah siswa yang mampu memperbaiki kesalahan atau kekurangan dalam proses pembelajaran adalah 29 siswa dari seluruh siswa kelas 1D dengan presentase sebesar 93,5\%. Aktivitas belajar yang ketiga jumlah siswa yang menyimpulkan materi pembelajaran dengan kata-katanya sendiri adalah 25 siswa dari seluruh siswa kelas 1D dengan presentase sebesar 80,6\%.

$$
\begin{aligned}
& \text { Nilai Rata-Rata }=\frac{\sum X}{\sum N} \\
& =\frac{90,396+94,6 \%+87,196+88,1 \% 6}{4} \\
& =\frac{360,196}{4} \\
& =90 \% \\
& \text { Adapun kriteria taraf keberhasilan } \\
& \text { tindakan yaitu : }
\end{aligned}
$$

$90 \% \leq \mathrm{NR} \leq 100 \%=$ Sangat Baik

$80 \% \leq \mathrm{NR} \leq 90 \% \quad=$ Baik

$70 \% \leq \mathrm{NR} \leq 80 \% \quad=$ Cukup

$60 \% \leq \mathrm{NR} \leq 70 \% \quad=$ Kurang

$0 \% \leq \mathrm{NR} \leq 60 \% \quad=$ Sangat Kurang

Pada data menunjukkan bahwa nilai rata-rata yang diperoleh dari empat aspek aktivitas siswa kelas 1D SDN Jajartunggal III Surabaya adalah $90 \%$. Berdasarkan taraf keberhasilan tindakan di atas, maka taraf keberhasilan aktivitas siswa dalam kategori Sangat Baik.

Peneliti melakukan wawancara dengan guru ketika selesai pembelajaran di kelas. Peneliti mewawancarai guru di ruang kelas ID. Peneliti mewawancarai guru sesuai dengan pedoman wawancara yang sudah disusun sebelumnya yaitu berkaitan dengan lama mengajar di SDN Jajartunggal III Surabaya, lama mengajar dikelas 1D, jumlah peserta didik kelas $1 \mathrm{D}$, metode pembelajaran yang sering digunakan pada pembelajaran melengkapi puisi, respon siswa terhadap pembelajaran, apakah dalam proses pembelajaran pernah menggunakan metode probing prompting, bagaimana hasil belajar siswa antara tidak menggunakan metode probing prompting dan menggunakan metode probing prompting, apakah guru merasa leluasa dalam mengajar dengan menggunakan metode probing prompting, bagaimana kesan guru setelah menerapkan metode probing prompting pada pembelajaran, apakah ada kesulitan pada saat menjelaskan materi, bagaimana aktivitas siswa selama pembelajaran dengan menggunakan metode probing prompting. Dari pertanyaan-pertanyaan di atas, dapat disimpulkan bahwa guru menerapkan metode probing prompting sesuai materi pembelajaran yang akan disampaikan. Aktifitas guru dalam pembelajaran sangat leluasa ketika menggunakan media ular tangga. Respon siswa ketika 
guru menerapkan media pembelajaran, siswa lebih memperhatikan pelajaran, lebih berkonsentrasi, menyukainya dan senang. Ketika siswa senang dalam mengikuti pembelajaran maka siswa memahami penjelasan yang telah disampaikan oleh guru. Hasil belajar siswa terdapat peningkatan yaitu pada saat tidak menggunakan metode probing prompting masih banyak siswa yang nilainya dibawah 75, sedangkan pada saat menggunakan metode probing prompting siswa yang mendapat nilai 75 meningkat, namun ada beberapa siswa yang slow learning jadi memerlukan bantuan dan bimbingan dari guru. Berikut ini akan dibahas tentang mengetahui keefektifan dalam penggunaan metode pembelajaran probing-prompting

\section{IDENTITAS NARASUMBER}

$\begin{array}{ll}\text { Nama } & \text { : Rizky Widyaningrum } \\ \text { Jenis Kelamin } & \text { : Perempuan } \\ \text { Umur } & : \text { 28 Tahun } \\ \text { Agama } & : \text { Islam } \\ \text { Pendidikan } & : \text { S1 PGSD UNESA } \\ \text { Jabatan } & : \text { Guru Kelas ID }\end{array}$

Tabel 5. Hasil wawancara dengan guru

\begin{tabular}{lll}
\hline NO & PERTANYAAN & JAWABAN \\
\hline 1 & Berapa lama ibu & 3 tahun \\
& mengajar di SDN & \\
& Jajartunggal III \\
& Surabaya?
\end{tabular}

2 Berapa lama ibu 6 bulan mengajar dikelas 2-A?

3 Berapa jumlah 31 siswa , peserta didik siswa yang belajar perempuan dikelas ibu saat 14 orang ini? dan siswa laki-laki 17 orang
4
metode
Biasanya
pembelajaran
yang sering
digunakan pada
pembelajaran
melengkapi puisi
?

5

Bagaimana
respon siswa
terhadap
pembelajaran?

Memerhatik

an

pembelajara

$\mathrm{n}$, tetapi

terkdang

juga kurang

memerhatik

an jika

siswa sudah

bosan

6 apakah dalam Belum

proses pernah

pembelajaran

pernah

menggunakan

metode probing

prompting?

7 Apakah dengan Sangat metode probing leluasa prompting, ibu sekali merasa leluasa dalam mengajar?

$\begin{array}{ll}\text { Bagaimana kesan } & \text { Tertarik, } \\ \text { anda setelah } & \text { tetapi saya } \\ \text { menerapkan } & \text { kira siswa } \\ \text { metode probing } & \text { bermain ular } \\ \text { prompting? } & \text { tangganya } \\ & \text { itu } \\ & \text { mengukur } \\ & \text { panjang } \\ & \text { jarak antara } \\ & \text { satu kotak } \\ & \text { ke kotak } \\ & \text { lain, } \\ & \text { ternyata } \\ & \text { enggak di } \\ & \text { setiap kotak }\end{array}$


terdapat

soalnya

masing-

masing, jadi

ya kreatif

sih

9

Apakah ada Belum ada
kesulitan pada
saat menjelaskan
materi saat
menggunakan
metode probing
prompting?

10

\begin{tabular}{ll} 
Apa saran ibu & Semoga \\
untuk siswa-siswi & lebih \\
kelas 1D ini? & ditingkatkan \\
& dalam hal \\
& ketertiban, \\
& lebih \\
& antusias lagi \\
& dalam \\
& pembelajara \\
& n, semoga \\
& lebih pintar \\
\hline
\end{tabular}

Berdasarkan hasil wawancara dengan guru diatas dapat disimpulkan bahwa guru sangat leluasa mengajar dan siswa pun senang dengan metode probing prompting dalam melengkapi puisi siswa kelas I SDN Jajartunggal III Surabaya.

Berdasarkan hasil analisa data diatas menunjukkan bahwa (1) hasil belajar siswa mencapai ketuntasan klasikal sebesar 83,87 \% (ketuntasan terpenuhi); (2) hasil observasi aktivitas siswa dalam pembelajaran sebesar $90 \%$ (kategori aktif terpenuhi); dan (3) hasil wawancara guru leluasa dalam mengajar (kategori positif terpenuhi).

Pada penelitian ini juga mengacu pada penelitian-penelitian sebelumnya. Penelitian-penelitian tersebut antara lain (1) pada tahun 2016 penelitian Taufik Nur Rahmadi dengan judul Pengaruh Penerapan Metode Probing-Prompting pada Pembelajaran IPA SMP Kelas VII Terhadap Kemampuan Berpikir Kritis Siswa dengan hasil terdapat perbedaan kemampuan berpikir kritis antara kelas VII yang menggunakan metode probing-promptingvdan kelas VII yang menggunakan metode direct instruction pada pembelajaran IPA di SMP N 4 Wonosari semester genap tahun pelajaran 2015/2016 dengan nilai (thitung $=3,018>$ ttabel $=2,007$ ) pada taraf signifikansi 5\%.; dan 2) besarnya pengaruh dari penerapan metode pembelajaran probing prompting terhadap kemampuan berpikir kritis siswa kelas VII SMP Negeri 4 Wonosari semester genap tahun pelajaran 2015/2016 adalah $62,61 \%$ dari pengambilan data menggunakan instrumen tes dan 69,72\% menggunakan instrument nontes; (2) pada tahun 2015 penelitian Ani Royani dengan judul Penerapan Metode Probing Prompting nntuk Meningkatkan Motivasi Belajar Siswa Bidang Studi IPS Kelas VII SMP Negeri 3 Palimanan Cirebon dengan hasil Penggunaan metode pembelajaran Probing Prompting dalam pembelajaran IPS (Ekonomi) dapat diterapkan dengan baik pada siswa kelas VII E SMP Negeri 3 Palimanan Cirebon. Hal ini dapat dilihat dari hasil observasi guru dan aktivitas siswa. Pada siklus I hasil observasi aktivitas siswa sebesar $57.5 \%$ sedangkan kinerja guru sebesar $65 \%$ dan ketuntasan belajar klasikal sebesar $27.77 \%$. Pada siklus II observasi aktivitas siswa sebesar $80 \%$ sedangkan kinerja gurunya sebesar $82.5 \%$ dan ketuntasan belajar klasikal sebesar $52.77 \%$. Adapun pada siklus III observasi aktivitas siswa sebesar $92.5 \%$ sedangkan kinerja gurunya sebesar 97.5 $\%$ dan ketuntasan belajar klasikalnya sebesar $100 \%$, dari hasil pengamatan 
peningkatan motivasi belajar siswa dapat di simpulkan sebagai berikut. Pada siklus I siswa yang termotivasi dalam belajar pada pokok bahasan kegiatan pokok ekonomi sebanyak 10 siswa dengan nilai ketuntasan belajarnya sebesar $27.77 \%$. Pada siklus II siswa yang termotivasi dalam belajar dalam pokok bahasan kegiatan pokok ekonomi sebanyak 19 siswa dengan nilai ketuntasan belajarnya sebesar $52.77 \%$. Kemudian pada siklus III siswa yang termotivasi dalam belajar dalam pokok bahasan kegiatan pokok ekonomi sebanyak 36 siswa dengan nilai ketuntasan belajarnya sebesar $100 \%$ tuntas. Sesuai dengan KKM yaitu 75 . Semua siswa sudah mencapai KKM maka oleh karena itu $100 \%$ ini termasuk kategori sangat baik, peningkatan hasil belajar siswa pada materi kegiatan pokok ekonomi setelah menggunakan metode Probing Prompting sebagai berikut. Pada siklus I hasil belajar siswa pada setiap akhir siklus nilai rata-rata siswa sebesar 67.22 kemudian pada siklus II hasil belajar dengan nilai ratarata siswa sebesar 73.33 dan pada siklus III hasil belajar siswa nilai rataratanya sebesar 83.75 dengan kategori sangat baik sebab berada pada rentang 81\%-100. Hal ini menunjukan bahwa dalam masingmasing siklus ini terlihat adanya suatu peningkatan karena sudah mencapai KKM; (3) penelitian Fajar Gumelar pada tahun 2016 dengan judul Efektivitas Metode Probing Prompting Learning dalam Pembelajaran Menulis Argumentasi dengan hasil kemampuan menulis argumentasi kelas eksperimen sebelum mengikuti pembelajaran menggunakan metode probing prompting learning berada dalam kategori kurang. Hal ini terbukti dari rata - rata nilai pretest menulis argumentasi kelas eksperimen adalah 65,65. Kemampuan menulis argumentasi kelas eksperimen setelah mengikuti pembelajaran menggunakan metode probing prompting learning berada dalam kategori yang lebih baik. Hal ini terbukti dari rata - rata nilai postes menulis argumentasi kelas eksperimen adalah 76,4. Perubahan nilai rata - rata tersebut menjadi bukti adanya pengaruh metode pembelajaran probing prompting learning terhadap kemampuan siswa dalam menulis argumentasi. Rata - rata kemampuan menulis argumentasi kelas kontrol sebelum mendapatkan perlakukan pembelajaran oleh guru yang lain adalah 66,06. Sedangkan sesudah mendapatkan perlakuaan pembelajaran yang dilakukan guru Bahasa Indonesia yang lain dengan tidak menggunakan metode pembelajaran probing prompting learning adalah 72,9. Terdapat perbedaan yang signifikan antara kemampuan menulis argumentasi peserta didik di kelas eksperimen yangmendapatkan perlakuan pembelajaran dengan menggunakan metode probing prompting learning dengan kemampuan menulis argumentasi peserta didik kelas kontrol yang mendapatkan perlakukan pembelajaran dengan metode pembelajaran yang lain. Berdasarkan perhitungan uji t, diperoleh thitung sebesar 2,59 sedangkan tabel $(\alpha 0,05)$ diperoleh sebesar 2,03. Maka dapat kita ketahui ttabel < thitung > tabel yaitu 2,03< 2,59>2,03 sehingga $\mathrm{H}_{1}$ diterima. Oleh karena itu dapat disimpulkan $\mathrm{H}_{1}$ diterima sedangkan $\mathrm{Ho}$ ditolak, artinya terdapat perbedaan yang signifikan antara kemampuan menulis argumentasi peserta didik kelas eksperimen dengan peserta didik kelas kontrol. Hal tersebut menandakan bahwa penggunaan metode probing prompting learning pada pembelajaran menulis argumentasi lebih dapat meningkatkan kemampuan menulis argumentasi peserta didik dibanding dengan metode pembelajaran 
yang telah digunakan guru bahasa Indonesia yang lain saat pembelajaran argumentasi; (4) penelitian Kariani dkk pada tahun 2014 dengan judul Model Problem Based Learning Menggunakan Metode Probing - Prompting Berpengaruh Terhadap Hasil Belajar IPA Siswa dengan hasil analisis uji hipotesis menggunakan uji $\mathrm{t}$ diperoleh thitung $>$ ttabel pada taraf signifikansi $5 \%(\alpha=0,05)$ dengan $\mathrm{dk}=78$ yaitu thitung $=4,83>$ ttabel $=2,00$. Selain itu, berdasarkan hasil penelitian serta analisis yang telah dilakukan menunjukkan pula bahwa ratarata nilai pada kelompok eksperimen lebih besar dibandingkan dengan rata-rata nilai pada kelompok kontrol yaitu $=80,34>$ $=71,17$. Hal ini menunjukkan bahwa hipotesis alternative (Ha) diterima yang berarti terdapat perbedaan yang signifikan hasil belajar IPA antara siswa yang dibelajarkan melalui penerapan model Problem Based Learning menggunakan metode ProbingPrompting dengan yang dibelajarkan melalui pembelajaran konvensional pada siswa kelas V SD Negeri 21 Pemecutan Tahun Ajaran 2013/2014. Berdasarkan perbedaan nilai rata-rata kedua kelompok dan hasil uji hipotesis, maka dapat disimpulkan bahwa penerapan model Problem Based Learning menggunakan metode Probing-Prompting berpengaruh terhadap hasil belajar IPA siswa kelas V SD Negeri 21 Pemecutan Denpasar Utara Tahun Ajaran 2013/2014.

\section{KESIMPULAN}

Berdasarkan hasil penelitian pada bagian sebelumnya, metode probingprompting mampu meningkatkan kemampuan melengkapi puisi siswa sekolah dasar. Hal ini didukung oleh data hasil belajar, pengamatan atau observasi, dan data hasil wawancara siswa kelas 1D SDN Jajartunggal III
Surabaya. Metode probing-prompting dalam kemampuan melengkapi puisi siswa sekolah dasar, diharapkan dapat menjadi pertimbangan bagi guru kelas I untuk mengembangkan pembelajaran dengan implementasi metode probingprompting pada mata pelajaran lain yang sesuai. Kepada pihak sekolah untuk memfasilitasi metode probing-prompting agar guru dapat memilih metode pembelajaran yang sesuai dengan pembelajaran yang diajarkannya sehingga siswa lebih aktif dalam mengikuti pembelajaran yang disampaikan oleh guru. Sedangkan bagi penelitian selanjutnya, penelitian ini dapat digunakan sebagai bahan rujukan untuk melakukan penelitian tentang metode pembelajaran khususnya metode probing-prompting.

\section{REFERENCES}

Citraningrum, D. M. (2016). Menulis Puisi Dengan Teknik Pembelajaran Yang Kreatif. Jurnal Umum Jember, $\quad 1(1), \quad 82$. http://jurnal.unmuhjember.ac.id/in dex.php/BB/article/view/75/55

Dewi, O., \& Kocimaheni, A. A. (2019). Pengaruh Penggunaan Metode Pembelajaran Probing Prompting Learning (PPL) Terhadap Kemampuan Membaca Kosakata Bahasa Jepang Siswa Kelas XI IPA 1 SMAN 1 Papar Kediri Tahun Ajaran 2018/2019. HIKARI, 3(2), 1-9. https://jurnalmahasiswa.unesa.ac.id /index.php/kejepanganunesa/article/view/30569/27855

Fadhillah, D. (2019). Pengaruh Metode Tebak Kata terhadap Keterampilan Menulis Puisi Siswa Kelas IV SDN Taman Cibodas Kota Tangerang. Silampari Bisa: Jurnal Penelitian Pendidikan Bahasa 
Indonesia, Daerah, Dan Asing, 2(1), 118-128. https://doi.org/10.31540/silamparib isa.v2i1.332

Firdaus, E. F. (2019). Pengaruh Keaktifan Siswa dalam Pembelajaran Metode Probing Prompting terhadap Kemampuan Pemecahan Masalah Matematis Materi Logika. JES-MAT, 5(2), 137-144.

https://www.journal.uniku.ac.id/in dex.php/JESMath/article/view/192 $5 / 1487$

Ika, M., \& Riana, D. L. (2016). Hubungan Minat Baca dan Kebiasaan Membaca Karya Sastra Terhadap Kemampuan Menulis Puisi. Jurnal Semantik STKIP Siliwangi, 5(2), 15-31. https://doi.org/10.22460/semantik. 5.2.

Kariani, N. K., Kt, D. B., Semara, N., \& Ardana, I. K. (2014). Model Problem Based Learning Menggunakan Metode Probing Promting Berpengaruh terhadap Hasil Belajar IPA Siswa Jurusan Pendidikan Guru Sekolah Dasar, FIP Universitas Pendidikan Ganesha. Jurnal Mimbar PGSD Universitas Pendidikan Ganesha, 2(1).

https://ejournal.undiksha.ac.id/inde x.php/JJPGSD/article/view/3098

Meilasari, N. R., Junianto, \& Mustika, I. (2018). Efektivitas Penggunaan Metode Image Streaming dalam Pembelajaran Menulis Cerita Pendek pada Siswa Kelas XI SMA Darul Falah Cihampelas. Parole Jurnal Pendidikan Bahasa Dan Sastra Indonesia, 1(5), 707-712. https://journal.ikipsiliwangi.ac.id/i ndex.php/parole/article/view/972

Oktaria, D., Andayani, \& Saddhono, K. (2017). Penguasaan Kalimat Efektif sebagai Kunci Peningkatan Keterampilan Menulis Eksposisi (The Mastery of Effective Sentences as the Key to Improve Exposition Writing Skill). Metalingua, 15(2), 165--177.

Rahmadani, P., Kaswari, \& Rosnita. (2015). Penggunaan Metode Latihan (Drill) untuk Meningkatkan Kemampuan Menulis Puisi Siswa Kelas III C. Jurnal Pendidikan Dan Pembelajaran Khatulistiwa, 4(9). http://jurnal.untan.ac.id/index.php/j pdpb/article/view/11431/10829

Susilo, S. V., \& Ramdiati, T. (2019). Penerapan Model Multiliterasi untuk Meningkatkan Keterampilan Menulis Karangan Persuasi pada Mata Pelajaran Bahasa Indonesia di Sekolah Dasar. Jurnal Cakrawala Pendas, 5(1), 24-31. http://www.jurnal.unma.ac.id/inde x.php/CP/article/view/1199/1127 